\title{
Effect of Inquiry-Based Learning Method Supported by Metacognitive Strategies on Fourth-Grade Students' Problem-Solving and Problem-Posing Skills: A Mixed Methods Research*
}

\author{
Ramazan Divrik"*a, Pusat Pilten ${ }^{b}$, Ayşe Mentiş Taş
}

$\begin{array}{ll}\text { Received } & : \text { 21 June } 2020 \\ \text { Revised } & : \text { 13 November } 2020 \\ \text { Accepted } & : \text { 30 December } 2020 \\ \text { DOI } & : \text { 10.26822/iejee.2021.191 }\end{array}$

"This article was produced from the PhD dissertation titled "Teachers' Opinions about Using Inquiry-Based Learning Method in 4th Grade Mathematics Lesson and Its Effects on Students' Problem Solving and Problem Posing Skills."

'A certain portion of this study has been presented in $\checkmark$ INES Human and Civilization Congress from Past to Future in 17-21 April 2019, Antalya-Turkey.

Correspondance Details: Ramazan Divrik. Ministry of National Education, Afyonkarahisar, Turkey. E-mail: rdivrik42@gmail.com

ORCID: http://orcid.org/0000-0002-7126-7664

bpusat Pilten. Khoja Akhmet Yassawi International Kazakh-Turkish University, Turkistan, Kazakhstan. E-mail: ppilten@ayu.edu.kz

ORCID: http://orcid.org/0000-0001-6032-5526,

- Ayşe Mentiş Taş. Ahmet Keleşoğlu Faculty of Education, Necmettin Erbakan University, Konya, Turkey. E-mail: aysementistas@hotmail.com ORCID: http://orcid.org/0000-0002-1175-812X

\begin{abstract}
This study aimed to evaluate the effectiveness of the inquiry-based learning method supported by metacognitive strategies on students' problem-solving and problem-posing skills. The research was conducted in two stages using an exploratory sequential design, which is one of the mixed methods research. The case study design was used in the first stage, while the quasi-experimental design with the pretest and posttest for control group was employed in the second stage. The method that is considered effective in students' gaining problem-solving and problem-posing skills was determined in the first stage. In the second stage, the designated method supported by metacognitive strategies was tested with 63 fourth-grade students. The data for the first stage of the study were collected through interviews held with 12 primary school teachers, the mathematics curriculum, and a group of 10 experts' opinions on the methods in the relevant literature. A content analysis and Lawshe's method were employed to analyze the data at hand. Data in the second stage were collected using the problem-solving skills test and problem-posing skills test. The Mann-Whitney $U$ test was used in the analysis of unrelated measurements, whereas the Wilcoxon signed ranks test was employed in the analysis of related measurements. The analysis results in the first stage revealed that the inquiry-based learning method might be effective in improving students' problemsolving and problem-solving skills. Thus, it was decided to utilize this method in the second stage. The results of the analysis in the second stage showed that the inquiry-based learning method supported by metacognitive strategies and the inquiry-based learning method could be effective in developing students' problem solving and problem-posing skills. Moreover, it was concluded that the methods applied were more effective in developing problem-solving skills and structured problem-posing skills of the students from subdimensions compared to the control group, but not effective in the development of semi-structured and free problemposing skills from sub-dimensions.
\end{abstract}

Keywords:

Problem-Solving, Problem-Posing, Methods and Techniques,

Inquiry-Based Learning, Metacognitive Strategies 


\section{Introduction}

Problem-solving and problem-posing are considered two important skills located at the center of the mathematics curriculum (Ministry of National Education [MoNE], 2018; National Council of Teachers of Mathematics [NCTM], 2000). While problem-solving is defined as the process of finding an appropriate solution for a new and more complex situation using students' previous knowledge (Baykul, 2014; Mayer, 2002; NCTM, 2000); problem-posing is defined as the developing new questions or problems to discover a particular situation and creating new problems based on the solution of a given problem (Cai \& Hwang, 2002; English, 2003; Silver, 1994).

Problem-solving is a meaningful learning process that expands, deepens, and consolidates mathematical knowledge (MoNE, 2015). Problem-posing is also as important as problem-solving and even an important endeavor that involves mathematical inquiry beyond problem-solving skills (Gonzales, 1998; Silver \& Cai, 2005). Researchers claimed that there is a close relationship between problem-solving and problemposing skills in development of mathematical thinking and creativity, and these skills support each other (Gonzales, 1998; Kilpatrick, 1987; Lowrie, 2002; Rosli, 2013; Stoyanova, 2005). Therefore, problem-solving and problem-posing activities should be frequently included to develop students' mathematical creativity (Kilpatrick, 1987; Mamona-Downs, 1993).

To provide students with problem-solving and problem-posing skills, problem-solving and problemposing should be addressed as a process rather than a subject or task (NCTM, 2000; Stoyanova \& Ellerton, 1996). Therefore, learning environments should be organized in such a way that allows students to be occupied with problems and creative. Due to the importance attributed to problem-solving and problem-posing and comprehensive teaching of such skills, it is emphasized that classroom environments should be created where students are able to solve problems in various ways and share their thoughts about the problem-solving and problem-posing process with their teachers and peers easily (MoNE, 2005; 2018). For this purpose, students' problemsolving and problem-posing skills were examined by designing different learning environments (Akkaş, 2014; Divrik, 2020; Erümit, 2014; Kanbur Tekerek \& Argün, 2019; Karataş \& Baki, 2017; Katrancl, 2014; Polat, 2009; Rosli, 2013; Turhan \& Güven, 2014; Yazlık, 2015). In this study, the inquiry-based learning method, a studentcentered teaching approach enabling students to create their questions and structure their knowledge, was used (Hammerman, 2006; Keller, 2001; Llewellyn, 2002).
The inquiry-based learning method is a technique in which teachers present a problem and students try to solve the problem by collecting data for the problem. This method enables students to ask questions, investigate, analyze information, and transform the data into useful information (Perry \& Richardson, 2001; Woolfolk, 2001). Studies revealed that lessons taught with an inquiry-based learning method have a positive effect on students' behaviors and motivations (Camenzuli \& Buhagiar, 2014; Caswell \& LaBrie, 2017; Kogan \& Laursen, 2013; Yavuz et al., 2018; Zhang, 2015). The same studies revealed that students' mathematics achievement increased, their anxiety levels decreased, and they enjoyed these lessons.

Studies also underscored the need to make arrangements that enable students to develop their metacognitive knowledge and skills and manage their own learning processes consciously (Aşık, 2015; Erdoğan, 2013; Goldberg \& Bush, 2003; Nelson, 2012). In this context, another element to be useful in mathematics teaching is metacognition, which is defined as thinking about thinking (Blakey \& Spence, 1990). Metacognition means the knowledge of the structure and operation of one's cognitive system and an individual's awareness of planning, monitoring, and evaluation processes in solving a mathematical problem (Flavell, 1979; Özsoy, 2007; Pugalee, 2001; Schoenfeld, 1987; Senemoğlu, 2013).

Some metacognitive strategies are used to create a supportive classroom environment that will encourage the development of students' metacognitive skills and enable them to take responsibility for their learning (Barın, 2016; Georghiades, 2004; Lin, 2001; Tian, 2016; Vula et al., 2017; Weaver, 2012). These strategies are defined as a series of processes used to control cognitive effectiveness in achieving a specified goal (Flavell, 1979; Gama, 2004; Schraw, 1998; Schraw \& Moshman, 1995). Therefore, students have the opportunity to make the necessary planning, monitoring, and evaluating their learning processes while performing this series of procedures. In this respect, it would be worthwhile to conduct comprehensive research on the use of metacognitive strategies for primary school students.

In line with the aforementioned context, the study used two different methods. The first method was the inquiry-based learning method, while the second one was the inquiry-based learning method supported by metacognitive strategies. These methods are considered to improve the fourth-grade students' problem solving and problem posing skills. Thus, the study aimed to investigate the effect of these two methods on students' problem solving and problem posing skills. The study, in this context, has the following research questions: 
For fourth-grade students to gain problem-solving and problem-posing skills:

1. Which method can be effective according to teachers' opinions?

2. Which method can be effective considering the directions in the curriculum?

3. Which method can be effective considering expert opinions on the methods in the relevant literature?

4. Does the improvement of their problemsolving skills differ significantly?

5. Does the improvement of their problemposing skills (structured, semi-structured, and free) differ significantly?

\section{Methodology}

\section{Research Design}

In this research, an exploratory sequential mixed method design was used. In this design, priority is given to collecting and analyzing qualitative data and the process begins with them. According to the findings, the researcher begins applying the second stage, the quantitative stage, and tests or generalizes the primary results. They explain how they build quantitative data on primary qualitative data (Creswell \& Plano-Clark, 2015).

In this study, a single-case research design, where more than one sub-dimension or unit in a single case nested, was used to obtain primary qualitative data (Yin, 1984). While the case studied here was to determine the method that could be effective in teaching problem-solving and problem-posing skills, the units of analysis of the case were the opinions of teachers, the curriculum, and expert opinions on the methods included in the relevant literature. Considering the best method that could be effective in developing students' problem-solving and problemposing skills, the study adopted this method for the second stage of the research.

In collecting and analyzing quantitative data as a secondary case, a quasi-experimental study was conducted in the trial model with the pretest and posttest control group. Studies that used experimental model tested the effect of the experimental process on the dependent variable. Thus, they added a high statistical power to the research and allowed the findings to be interpreted in the context of cause and effect (Büyüköztürk, 2012). In the experimental section, the effect of activities conducted with the inquirybased learning method supported by metacognitive strategies and inquiry-based learning on the problemsolving and problem-posing skills of fourth-grade primary school students was examined.

\section{Study Group}

The study group in the qualitative part of the study consisted of 12 primary school teachers and the mathematics curriculum. Criterion sampling, one of the purposeful sampling methods, was used to determine primary school teachers. The basic understanding of this type of sampling is to examine the situations that meet a predetermined set of criteria (Yıldırım \& Şimşek, 2006). For this purpose, a list of criteria was prepared by the researchers. These criteria were listed as the inclusion of three teachers from each grade level in the research. Teachers were selected from different schools in a district center and villages. The selection of the teachers was made by considering the socio-economic characteristics of the schools, tenure of teachers, and educational degree of the teachers, and the expression of the teachers that they paid attention to the application of different methods in mathematics courses.

The study group in the quantitative part consisted of 63 fourth-grade students studying in three classes in the second semester of the 2017-2018 academic year. In the experimental part of the study, two experimental groups and a control group were determined as the effects of two independent variables (inquiry-based teaching supported by metacognitive strategies and inquiry-based teaching) on dependent variables (problem-solving and problem-posing skills) were investigated.

In determining the experimental and control groups, the first-term mathematics grade averages of the three classes were examined. As a result of the exploration, the average of mathematics achievement of the classes was calculated as 82.72, 80.15, and 79.86. According to these averages, the mathematics achievements of the groups were found to be equivalent.

After the groups were determined to be equivalent, two experimental groups and one control group were selected by the neutral assignment method. Twentytwo students (10 girls [45.45\%] and 12 boys [54.55\%]) were included in the first experimental group; 20 students (nine girls [45\%], 11 boys [55\%]) were included in the second experimental group; and 21 students (12 girls [57.1\%] and nine boys [42.9\%]) were included in the control group. These data show that the numbers of students in the experimental and control groups were equal and the distribution of the participants in the study groups by gender within the groups was close to each other. 


\section{Data Collection Tools}

\section{Semi-structured interview form}

This form consisted of the following two dimensions: personal information and interview questions. The personal information dimension of the form aimed to collect demographic information of the participants, such as gender, tenure, educational degree, and grade level that the participants teach were provided. Besides, an open-ended question was added to the interview question part of the questionnaire, aiming to collect data in accordance with the purpose of the research. Furthermore, expert opinions were consulted while preparing the form.

While developing the form, a draft form consisting of two questions was prepared first. Later, a pilot study was conducted by applying this draft form to two primary school teachers. During the pilot study, primary school teachers reported that the two questions were similar. Thus, these two questions were decided to combine. As a result of these studies, a final form consisting of the following single question was obtained: Is it possible to apply different methods in mathematics classes for students to gain problemsolving and problem-posing skills by considering the grade level that you teach, and could you please explain how these methods should be?

\section{Form for expert opinion}

This form included approaches, methods, and techniques that can be used in mathematics teaching by scanning the relevant literature. An expert group of 10 people was formed to fill in this form. This expert group included mathematics teachers, primary school teachers, and academicians who conducted studies on mathematics education. The expert group was asked to evaluate the methods and techniques that could be effective in teaching problem-solving and problem-posing skills by using this form.

\section{Problem-solving skills test and problem-posing skills test}

The problem-solving skills test developed by the researchers consisted of 15 problems and the problemposing skills test consisted of 15 problem-posing situations. All questions in the problem-solving skills test consisted of open-ended questions. The questions included in the problem-posing skills test consisted of structured, semi-structured, and free problemposing situations (five pieces for each). A structured problem-posing presents a problem and poses a new problem out of it. A semi-structured problem posing is developing a new problem from a problem situation using instruments such as raw information, graphs, pictures, and tables. A free problem-posing is to pose a problem about the desired subject without giving any problem, data, figure, or problem situation. The problems and problem-posing situations in the tests consisted of questions in the learning domains of addition, subtraction, multiplication, division, and length measurement. In this way, it was aimed to enable students to solve and pose problems by using their four operations skills.

The opinions of three faculty members and eight primary school teachers were taken in the process of forming the tests. The Cronbach's alpha $(a)$ values of the problem-solving skills test for the first experimental group, the second experimental group, and the control group were .90, .91, and .75, respectively. The Cronbach's alpha (a) value for the problem-posing skills test for the first experimental group, the second experimental group, and the control group were .89, .86 , and .94 , respectively.

\section{Rubrics for the evaluation of problem-solving and evaluation of problem-posing}

These rubrics were developed by Katrancı (2014) to evaluate problem-solving skills and consist of five criteria. The rubrics aimed to evaluate the problemsolving processes of the students better by separating each criterion into sub-criteria. The highest score that students could get from this rubric for each question was 5, while the lowest score was 1. The Cronbach's alpha value of the rubric was 0.925 . The rubrics for the evaluation of problem-posing included four subdimensions and each dimension consisted of four criteria. The assessment criteria of the sub-dimensions were evaluated between 0 and 4 points, and each sub-dimension had the coefficients of the evaluation criteria. Thus, it is possible to observe them in detail in which stage they have deficiencies while evaluating students' problem-posing studies. The highest score that students could get from this rubric for each question was 14 , whereas the lowest score was 0 . The Cronbach's alpha score of the rubric was 0.932 .

\section{Observation forms for the evaluation of experimental procedures}

They were developed by the researchers to evaluate the teaching performed in the experimental groups. The forms were created by considering the application steps of the methods applied in the experimental groups. The aim was to set criteria for determining whether the experimental applications were functioned as planned or not. 


\section{Observation form for the evaluation of studies conducted in the control group}

The form was developed by the researchers to observe the problem-solving and problem-posing activities in the control group. Problem-solving and problemposing activities performed in the control group during the experimental process were determined through this form.

\section{Data Collection Process}

In the qualitative part, interviews were conducted with primary school teachers first. Each interview lasted approximately 30-40 minutes. Briggs (1986) stated that the interviewing, which is widely used in the field of social sciences, is an effective data collection method for obtaining information about individuals' experiences, opinions, complaints, feelings, attitudes, and beliefs (cited in Yıldırım \& Şimşek, 2006). Thereafter, the mathematics curriculum was examined through document analysis. According to Wiersma and Jurs (2005), document analysis is a technique used for data collection, systematic analysis, and evaluation of data.

Finally, the relevant literature was reviewed to determine teaching approach and techniques that could be employed in mathematics teaching. After the expert group was informed about the methods and techniques, they were asked to evaluate these methods and techniques that could be effective in teaching problem-solving and problem-posing skills. The data obtained from the experts were converted into statistical data using Lawshe's technique (critical values for Lawshe's content validity ratio) to determine the content validity ratios. Thanks to these rates, the methods that could be used were determined. The obtained data are presented in the findings section.

Furthermore, pretest and posttest were applied to the students in the experimental and control groups of the problem-solving skills test and problem-posing skills test to collect the quantitative data. The tests were applied to the students with similar characteristics to identify the response time of the tests and it was concluded that the two class hours $(40+40 \mathrm{~min})$ would be sufficient for the tests.

\section{An (inquiry + metacognition) application process for the first experimental group}

In the first experimental group, the application of an inquiry-based learning method supported by various metacognitive strategies was performed. The application was implemented for nine weeks by performing problem-solving and problem-posing activities in one class hour each day. One problem was solved and formed in each class hour. Forty-five problem-solving and 45 problem-posing practices were performed in 45 class hours. In addition, through the homework guide form, 20 problem-solving and 20 problem-posing practices were distributed to the students to solve them at home. In total, the students completed 65 problem-solving and problem-posing practices.

Various metacognitive strategies were used to develop students' metacognitive skills in the inquirybased learning environment, and thus, various materials were designed by the researcher by taking the expert opinions. These materials are problem-solving with guidance card / problemposing worksheet, problem-solving with behavior card / problem-posing worksheet, problem-solving / problem-posing worksheet, checklist, error evaluation form, peer evaluation form, reflective journal writing form, homework guide form, and self-assessment scale. These materials consisted of questions that improve students' metacognitive skills while solving and posing problems. After reading a problem or problem situation, the students solved and formed the problems by answering the questions included in each inquiry tread.

\section{The second experimental group (inquiry) application} process:

In the second experimental group, the process, including only the inquiry steps, was applied without performing metacognitive strategy teaching. In determining these steps, the inquiry steps introduced to encourage the application and use of inquiry-based learning in mathematics and science by bringing together 14 universities from 12 countries in Europe were used (Promoting Inquiry in Mathematics and Science Education Project [PRIMAS], 2010). In the practice process based on inquiry, worksheets, containing the same problems and problem-posing situations as the first experimental group were prepared as materials. The students completed 45 problem-solving and problem-posing activities for each in the classroom within 45 class hours and completed 20 problemsolving and problem-posing activities for each at home. The students completed a total of 65 problemsolving and problem-posing activities. However, expressions that improved metacognitive skills were excluded from these worksheets. The students were allowed to perform problem-solving and problemposing practices in accordance with the steps of "simplification and representation," "analyzing and solving," "interpretation and evaluation," "communicating and reflecting," and "reviewing the process." 


\section{The control group application process}

No instructional planning was made in the control group, and the normal process based on the textbook continued. However, during the teaching process in the control group, the students also dealt with the same problems and problem-posing situations used in the experimental groups. In addition, 20 problemsolving and problem-posing activities were provided for them to be solved at home.

\section{Data Analysis}

A content analysis was used to examine the interviews with the teachers and the mathematics curriculum, while the Lawshe's technique was used to analyze the expert opinions. The procedure in the content analysis was to bring similar data within the framework of certain concepts and themes together and interpret them in a way that the reader could understand (Yıldırım \& Ssimşek, 2006). In the content analysis, the teachers' names obtained during the interview process were kept confidential and were coded as T1, T2, T3, ... T12. Page numbers in the direct quotations obtained from the mathematics curriculum were given in the following form: pg.1, pg.2.

Lawshe's technique was used to analyze the expert opinions. A minimum of five and a maximum of 40 expert opinions are received through this technique (Yurdugül, 2005; Yurdugül \& Bayrak, 2012). The opinions of the expert group were scaled into the following three categories: "necessary," "useful but unnecessary," and "unnecessary." The calculation was then made over the number of experts who reported the item "necessary" (Ayre \& Scally, 2014).

Content validity ratios (CVR) were obtained by 1 minus of the ratio of the number of experts reporting the opinion of "necessary" for any item to the half of the total number of experts providing opinions on the item (Lawshe, 1975). CVRs varied between +1 to -1 . Ratios with 0 and negative values were directly excluded (Yurdugül, 2005). As the opinions from 10 experts were received in this study, the content validity criterion was found to be "0.62," and the evaluations were made according to this criterion in the findings section.

In the quantitative section, the pp graph, skewness, and kurtosis values were examined to determine whether the data showed a normal distribution to select the appropriate statistical method for the study and to decide the statistical procedures to be applied. The skewness/the standard error of skewness was found to be $>1.96$ and, thus, the data set variables did not show a normal distribution. Therefore, the Mann-Whitney $U$ test was used to analyze unrelated measurements in the comparison of pretest and posttest scores of the students in the experimental and control groups, and the Wilcoxon signed ranks test was used in the analysis of related measurements. The error margin in the research was accepted as .05.

In addition, the effect sizes were calculated to determine to what extent the independent variables affect the dependent variables. The effect size is a value used to determine how effective an examined case is (Yıldırım, 2015). In non-parametric tests, the effect size, as mentioned by Field (2009), was calculated using the formula $r=z / \sqrt{ } N$, and they were interpreted as small effect, moderate effect, and strong effect with the values of $r=0.10, r=0.30$, and $r=$ 0.50 , respectively.

\section{Results}

\section{The Results of the First Stage of the Study}

In the first sub-problem of the study, interviews with teachers were conducted to determine the method that could be effective for fourth-grade students to gain problem-solving and problem-posing skills. The findings obtained from the interviews with teachers are presented in Table 1.

As Table 1 presents, the opinions of teachers were grouped under six categories. During the creation of categories, the codes were identified, and expressions were analyzed according to these codes. Two teachers $(16.66 \%)$ reporting students could learn better with fun activities said that game-oriented methods could be effective. Two teachers (16.66\%) said that the methods that attract more students to arouse their interest and help them use their imagination could be efficient.

Three teachers $(25 \%)$ reported that the methods that could develop different perspectives could be effective in problem-solving and problem-posing practices. Two teachers (16.66\%) mentioned that the methods that could be understood by the students at different levels with low-attendance and attention deficit could be impressive. Two teachers (16.66\%) reported that the use of the methods in which the problem solutions are explained step-by-step could be effective. Furthermore, one teacher (8.34\%) reported that students should have different problem-solving and problem-posing methods to form and solve problems.

The findings of the analyses regarding the second sub-problem of the study are presented in Table 2. When Table 2 was analyzed, eight categories regarding the methods emphasized in the statements in the program were identified. The details of these categories revealed the following assumptions: 


\section{Table 1}

The Opinions of the Teachers Concerning the Applicability of Different Methods

\begin{tabular}{|c|c|c|c|}
\hline Category & $f(\%)$ & Code & Teacher statements \\
\hline Game-based & $2(16.66)$ & Game & 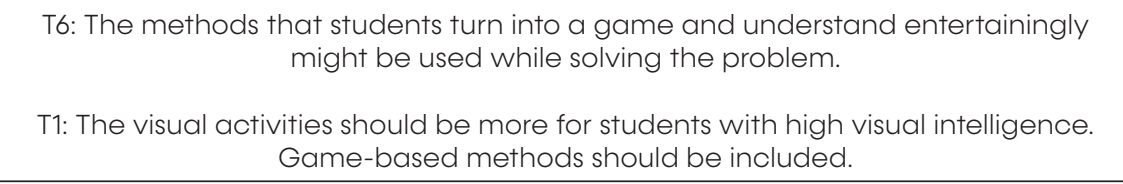 \\
\hline Attractive & $2(16.66)$ & Attention & $\begin{array}{c}\text { T2: Yes, the activities in the textbook seem very superficial and ordinary. I would } \\
\text { like methods that would draw children's attention more and would make them use } \\
\text { their imagination more to be included. } \\
\text { T8: As the practices in the book are very few, the presence of the methods that } \\
\text { attract the students' attention would increase diversity. }\end{array}$ \\
\hline $\begin{array}{l}\text { The one } \\
\text { containing } \\
\text { different } \\
\text { viewpoints }\end{array}$ & $\begin{array}{c}3 \\
(25)\end{array}$ & Method & $\begin{array}{l}\text { T4: I think that the methods that allow for posing more problems would be effec- } \\
\text { tive. By this means, the students could both pose and solve a problem they have } \\
\text { created by developing different viewpoints. } \\
\text { T11: The student would choose the shortest path to the solution or the most ap- } \\
\text { propriate way for their comprehension when solving or forming a problem. In this } \\
\text { respect, the introduction of different paths is important. Furthermore, the methods } \\
\text { that could contribute to the teacher's development of distinct ideas and increase } \\
\text { the student's attention. } \\
\text { T9: In mathematics course, we make the students deal with a great variety of } \\
\text { questions. As every problem has absolutely a few solutions, it would be good to } \\
\text { have the methods that bring in different perspectives. }\end{array}$ \\
\hline $\begin{array}{l}\text { Suitable for a } \\
\text { level }\end{array}$ & $2(16.66)$ & Level & $\begin{array}{l}\text { T7: Teaching could be easier if there were e different methods that can be easily } \\
\text { understood by the students with low attendance and with attention deficit. } \\
\text { T5: The comprehension and understanding level of each student } f \text { is not the same. } \\
\text { Therefore, different methods could appeal to different students. }\end{array}$ \\
\hline $\begin{array}{l}\text { The one } \\
\text { including } \\
\text { process steps }\end{array}$ & $2(16.66)$ & $\begin{array}{l}\text { Step-by- } \\
\text { step }\end{array}$ & $\begin{array}{l}\text { T12: In particular, the students with difficulties understanding what they read while } \\
\text { reading information about the problem. They have problems with misapplying the } \\
\text { information and inability to express it adequately. It could be good to use paths } \\
\text { with different process steps to eliminate these issues. } \\
\text { T3: The number of examples should be increased, and the existence of different } \\
\text { methods would enable the students to understand the stages of problem-posing. } \\
\text { Thus, the student will be able to solve and form the problem more easily. Because } \\
\text { books are inadequate on this subject. }\end{array}$ \\
\hline $\begin{array}{l}\text { The one } \\
\text { including } \\
\text { fiction }\end{array}$ & $1(8.34)$ & Fiction & $\begin{array}{c}\text { T10: Of course, the sample problem should be placed on the page so that the } \\
\text { student fictionalizes and solves it. Moreover, it would be better to reduce page } \\
\text { densities visually and increase the numbers. }\end{array}$ \\
\hline Total & $12(100)$ & & \\
\hline
\end{tabular}

the program emphasized the methods that direct the use of metacognitive knowledge and skills, in which time is effectively used, a teacher is a guide when needed, could be built on previous learning, individual differences are taken into account, active participation is provided and is open to necessary adaptations, could be effective.

In the third sub-problem of the research, expert opinions concerning the methods in the relevant literature, which could be effective in equipping fourthgrade students with problem-solving and problemposing skills, were examined. In determining these methods, Lawshe's technique was used to analyze the answers provided by the experts. The content validity ratio was 0.62 as 10 experts participated in the research. The methods that took a value above this rate were identified as effective methods in teaching problem-solving and problem-posing skills. The findings regarding expert opinions are presented in Table 3.
Table 3 shows the content validity ratios of the methods presenting the expert opinions. According to these ratios, the methods that are above the 0.62 content validity ratio calculated in the method section were considered effective methods. The methods with the highest value were identified as the inquirybased learning and problem-solving method. Also, the observation method, micro-teaching, simulation technique, six hat-thinking technique, role-playing method, demonstration method, show and tell method, and direct instruction method, which took 0 and negative values, were also determined as the methods and techniques that should not be used.

The findings obtained from the first stage of the research revealed that the activities should not be performed by rote learning methods that do not encourage the student to conduct research and think. Therefore, it has been observed that student-centered methods should be preferred in which students actively participate in the learning process, pose their 
Table 2

Expressions in the Program Regarding the Method that Could be Effective

\begin{tabular}{ccc}
\hline Category & Code & Teacher statements \\
\hline $\begin{array}{c}\text { Making using } \\
\text { the time effi- } \\
\text { ciently }\end{array}$ & Time & $\begin{array}{c}\text { "To pursue and insist on learning so that the individuals could organize their act of learning } \\
\text { individually or in groups, including effective time and knowledge management" (pg. 6). }\end{array}$ \\
\hline $\begin{array}{c}\text { Guidance } \\
\text { prepared by: }\end{array}$ & "Gapport & "Gaining, processing, and adopting new knowledge and skills as well as looking for guid- \\
ance support and take advantage of it..." (pg. 6).
\end{tabular}

Revealing preliminary information Preliminary information

Guidance

'Students' prior learning should be identified and opportunities for students to build new mathematical concepts on previous concepts should be provided through the activities that support effective learning and students should be encouraged in this process"(pg. 15).

"In the process of learning mathematical concepts, it is necessary and important for teachers to guide students to express their thoughts. In this context, through questions such as 'Have you ever encountered a problem similar to this problem? If so, do you remember the path you followed? Do you know what path would work to solve this problem?' the student should be allowed to demonstrate and strengthen the thinking process" (pg. 15).

\begin{tabular}{c}
$\begin{array}{c}\text { "As the individual is severely affected by internal and external dynamics such as educa- } \\
\text { tional level, course content, social environment, and school facilities, the priority in ensuring } \\
\text { the effectiveness of measurement and evaluation practices is expected from teachers and } \\
\text { training practitioners, instead of the curricula. At this point, originality and creativity are the } \\
\text { basic expectations of the teachers" (pg. 7). }\end{array}$ \\
\hline
\end{tabular}

"Due to the fact of individual differences, it is not appropriate to speak of a uniform method of measurement and evaluation involving all students, and de facto for all students. The academic development of the student cannot be evaluated by measuring a single method or a technique" (pg. 7).

Interest

"Individual differences derived from hereditary, environmental, and cultural factors manifest themselves also in terms of interest, need, and orientation. Alternatively, this includes inter-individual differences and differences within the individual. Individuals differ both from

$\begin{array}{ccc}\text { Safeguarding } & \text { Requirement } \\ \text { individual } & \text { others and are different from their characteristics. While an individual's abstract thinking } \\ \text { ability is strong, the same individual's painting ability could be weak" (pg. 8). }\end{array}$ differences

Measurement and

Evaluation

"Although development continues throughout life, the rate of this development varies according to the stages. Times, when the speed is high, are the risky and critical times in terms of development. Therefore, teachers are expected to be more sensitive to the situation of the student when the development speed is high" (pg. 8).

"Students' individual differences should not be neglected. Therefore, priority and importance should be given to the practices that put forward students' learning styles and strategies in mathematics teaching studies" (pg. 14).

"Multi-focused measurement-evaluation is essential. The measurement and evaluation practices are performed by the active participation of the teachers and students" (pg. 7).

The one providing active participation

Participation

Communication

"In the process of teaching and learning mathematics, the fact that students express their thoughts verbally plays an important role in internalizing, understanding, and structuring mathematical concepts. Students should also be encouraged to establish individual and inter-individual communication while demonstrating how they construct concepts in the teaching process" (pg.15).

"Although development continues throughout life, it is not in a single and an exemplary structure. It proceeds as phases and the developmental characteristics of individuals are different in each stage. The phases are not homogeneous in terms of their beginnings and

The one comprising necessary adaptations
Development

Teacher

Method endings. For this reason, the programs are structured with the utmost precision to take this into account. In the process of realizing the objectives and gains of the programs, the necessary adaptations are expected to be made by the teacher" (pg. 7).

"The individual and cultural differences among students should be considered in the implementation process of the program. In this context, appropriate methods and approaches should be preferred in the mathematics-teaching process" (pg.15).

\begin{tabular}{|c|c|c|}
\hline \multirow{2}{*}{$\begin{array}{l}\text { Making use of } \\
\text { metacognition }\end{array}$} & Problem-solving & $\begin{array}{l}\text { "The students will be able to express their thoughts and reasoning easily in the process of } \\
\text { problem-solving and see deficiencies or gaps in the mathematical reasoning of other" (pg. } \\
\text { 9). }\end{array}$ \\
\hline & Action & $\begin{array}{l}\text { "Education is given not only for 'knowing (thought),' but also for 'feeling (emotion)' and 'do- } \\
\text { ing (action),' therefore, only cognitive measures cannot be considered sufficient" (pg. 7). }\end{array}$ \\
\hline
\end{tabular}


Table 3

The Content Validity Ratios of Expert Opinions (CVR)

\begin{tabular}{|c|c|c|c|c|c|c|c|c|c|}
\hline $\begin{array}{l}\text { Approach/ } \\
\text { Method/ } \\
\text { Technique }\end{array}$ & $\begin{array}{l}\frac{0}{+} \\
\frac{0}{2} \\
\frac{0}{0} \\
\frac{1}{0} \\
\frac{0}{2}\end{array}$ & $\begin{array}{l}0 \\
\frac{1}{1} \\
\frac{0}{0} \\
0 \\
0 \\
0 \\
5 \\
\frac{1}{0} \\
\underline{0}\end{array}$ & $\begin{array}{l}0 \\
\frac{1}{0} \\
.0 \\
\frac{0}{0} \\
0 \\
\frac{0}{0} \\
\frac{0}{0} \\
\frac{0}{0} \\
\subseteq\end{array}$ & $\stackrel{\alpha}{>}$ & $\begin{array}{l}\text { Approach/ } \\
\text { Method/ } \\
\text { Technique }\end{array}$ & $\begin{array}{l}\frac{0}{0} \\
\frac{0}{0} \\
\frac{0}{0} \\
\frac{0}{0} \\
\frac{0}{2}\end{array}$ & $\begin{array}{l}0 \\
0 \\
\frac{1}{0} \\
0 \\
0 \\
0 \\
\frac{\varrho}{J} \\
\frac{1}{0} \\
\underline{0}\end{array}$ & $\begin{array}{l}0 \\
\frac{1}{0} \\
0 \\
\frac{0}{0} \\
0 \\
0 \\
\frac{0}{0} \\
\frac{0}{0} \\
\subseteq \\
\subseteq\end{array}$ & $\stackrel{\alpha}{>}$ \\
\hline Inquiry-based learning & 10 & 0 & 0 & 1 & Direct instruction method & 1 & 2 & 7 & -.8 \\
\hline Peer learning method & 9 & 1 & 1 & .8 & Question and answer method & 7 & 0 & 3 & .4 \\
\hline Active learning & 9 & 0 & 1 & .8 & Problem-solving method & 10 & 0 & 0 & 1 \\
\hline Programmed instruction & 6 & 3 & 1 & .2 & Demonstration method & 2 & 5 & 3 & -.6 \\
\hline Computer-aided instruction & 7 & 1 & 2 & .4 & Observation method & 5 & 2 & 3 & 0 \\
\hline Micro-teaching & 4 & 1 & 5 & -.2 & Role playing method & 4 & 2 & 4 & -.2 \\
\hline Teaching by team & 9 & 0 & 1 & .8 & Case study method & 7 & 2 & 1 & .4 \\
\hline Simulation technique & 4 & 2 & 4 & -.2 & Discussion method & 6 & 3 & 1 & .2 \\
\hline Six thinking hats technique & 4 & 2 & 4 & -.2 & Show and tell method & 2 & 2 & 6 & -.6 \\
\hline Brainstorming technique & 7 & 1 & 2 & .4 & Group working method & 9 & 0 & 1 & .8 \\
\hline Station technique & 6 & 1 & 3 & .2 & Project method & 8 & 1 & 1 & .6 \\
\hline
\end{tabular}

questions, work in collaboration by combining new information with previous information, and that is also entertaining, individual differences are supervised, communication is encouraged, and a teacher guides when necessary.

One of these methods in the first stage of the research was the inquiry-based learning method determined by analyzing teachers' opinions, the mathematics curriculum, and expert opinions. The inquiry-based learning method is a student-centered method in which students use their creativity in the process of creating knowledge by asking questions and conducting research. In the second stage of the study, an experimental study was designed to determine the effect of this method on students' problem-solving and problem-posing skills. In this designed experimental process, the effect of inquiry-based learning method supported by metacognitive strategies and inquirybased learning method on students' problem-solving and problem-posing skills were examined.

\section{The Results of the Second Stage of the Study}

The fourth sub-problem of the study was examined to determine whether there was a significant difference between the pretest and posttest scores of the problem-solving skills of the experimental and control groups.

The findings of the Mann-Whitney $U$ test conducted for the analysis of the problem- solving skills pretest scores of the experimental and control groups are shown in Table 4.

Table 4 shows that there was a statistically significant difference in favor of experimental group 1 between the experimental group 1 and the control group before the practices $(U=62.50, z=-4.09, p<.05)$, between the experimental group 1 and experimental group 2 in favor of experimental group $1(U=101, z=$ $-3.00, p<.05)$. The findings also revealed that there was no statistically significant difference between the experimental group 2 and control group $(U=145.50, z=$

\section{Table 4}

Analysis of Pretest Scores in Problem-Solving Skills

\begin{tabular}{|c|c|c|c|c|c|}
\hline Groups & $n$ & Mean rank & Rank total & $U$ & $p$ \\
\hline I. Experiment & 22 & 29.66 & 652.50 & \multirow{2}{*}{62.50} & \multirow{2}{*}{$.00^{\circ}$} \\
\hline Control & 21 & 13.98 & 293.50 & & \\
\hline II. Experiment & 20 & 24.23 & 484.50 & \multirow{2}{*}{145.50} & \multirow{2}{*}{.09} \\
\hline Control & 21 & 17.93 & 376.50 & & \\
\hline I. Experiment & 22 & 26.91 & 592 & \multirow{2}{*}{101} & \multirow{2}{*}{$.00^{*}$} \\
\hline II. Experiment & 20 & 15.55 & 311 & & \\
\hline
\end{tabular}




\section{iejee}

$-1.68, p>$.05). The mean scores of the groups revealed that the problem-solving skills of the first experimental group were higher than the second experimental group and the control group before applying the learning methods. It would be safe to say that the problem-solving skills of the second experimental group and the control group equaled to each other.

The results of the Mann-Whitney $U$ test conducted for the analysis of the problem-solving skills posttest scores of the experimental and control groups are shown in Table 5.

According to Table 5, after the experimental practices, the problem-solving skills of the students in the experimental group 1 compared to both the students in the control group $(U=46.50, z=-4.48, p<.05$, $r=-.68)$, and in the experimental group 2 ( $U=95.50, z=$ -3.14, $p<.05, r=-.48$ ) showed a statistically significant difference. In addition, the problem-solving skills of the experimental group 2 students were found to be higher than the control group $(U=117, z=-2.43, p<.05, r=$ -.53). The effect size values revealed that the inquirybased learning method supported by metacognitive strategies and inquiry-based learning significantly improved students' problem-solving skills compared to the learning process envisaged by the curriculum. Moreover, the inquiry-based learning method supported by metacognitive strategies improved students' problem-solving skills at a moderate level compared to the inquiry-based learning method.

Table 5

Analysis of Posttest Scores in Problem-Solving Skills

\begin{tabular}{|c|c|c|c|c|c|}
\hline Groups & $n$ & Mean rank & Rank total & $U$ & $p$ \\
\hline I. Experiment & 22 & 30.39 & 668.50 & \multirow{2}{*}{46.50} & \multirow{2}{*}{$.00^{*}$} \\
\hline control & 21 & 13.21 & 277.50 & & \\
\hline II. Experiment & 20 & 25.67 & 513 & \multirow{2}{*}{117} & \multirow{2}{*}{$.01^{*}$} \\
\hline control & 21 & 16.57 & 348 & & \\
\hline I. Experiment & 22 & 27.16 & 597.50 & \multirow{2}{*}{95.50} & \multirow{2}{*}{$.00^{*}$} \\
\hline II. Experiment & 20 & 15.28 & 305.50 & & \\
\hline
\end{tabular}

\section{Table 6}

Analysis of Pretest and Posttest Scores in Problem-Solving Skills

\begin{tabular}{|c|c|c|c|c|c|c|}
\hline Groups & Pretest posttest & $n$ & Mean rank & Rank total & $z$ & $p$ \\
\hline \multirow{3}{*}{ I. Experimental group } & Negative ranks & $3^{a}$ & 7 & 21 & \multirow{3}{*}{$-3.42^{*}$} & \multirow{3}{*}{.00} \\
\hline & Positive ranks & $19^{b}$ & 12.21 & 232 & & \\
\hline & Equal & $0^{\circ}$ & - & - & & \\
\hline \multirow{3}{*}{ II. Experimental group } & Negative ranks & $0^{a}$ & .00 & .00 & \multirow{3}{*}{$-3.92^{*}$} & \multirow{3}{*}{.00} \\
\hline & Positive ranks & $20^{b}$ & 10.50 & 210 & & \\
\hline & Equal & $0^{\circ}$ & - & - & & \\
\hline \multirow{3}{*}{ The control group } & Negative ranks & $3^{a}$ & 4.17 & 12.50 & \multirow{3}{*}{$-3.45^{*}$} & \multirow{3}{*}{.00} \\
\hline & Positive ranks & $17^{b}$ & 11.62 & 197.50 & & \\
\hline & Equal & $1^{\circ}$ & - & - & & \\
\hline
\end{tabular}


The results of the Mann-Whitney $U$ test conducted for the analysis of the structured problem-posing skills sub-dimension posttest scores of the experimental and control groups are presented in Table 8.

According to Table 8, after the experimental applications, both the students in the experimental group $1(U=128.50, z=-2.49, p<.05, r=-.38)$, as well as the students in experimental group $2(U=131.50, z=$ -2.06, $p<.05, r=-.32)$ structured problem-posing skills showed a statistically significant difference compared to the students in the control group. However, there was no statistically significant difference between the students' structured problem-posing skills in the first and second experimental groups $(U=199.50$, $z=-.52, p>$.05). The effect size values revealed that the inquiry-based learning method supported by metacognitive strategies and inquiry-based learning methods improved the students' problem-posing skills at a moderate level compared to the learning process predicted by the curriculum. However, the inquirybased learning method supported by metacognitive strategies was not more effective compared to the inquiry-based learning method.

The results of the Wilcoxon signed ranks test conducted for the students in the experimental and control groups regarding whether there was a statistically significant difference between the structured problem-posing skills sub-dimension pretest-posttest scores are shown in Table 9.

According to Table 9, in the experimental and control groups, a statistically significant difference was found in favor of posttest scores $(z=-4.11, p<.05, r=-.62 ; z=$ $-3.92, p<.05, r=-.62 ; z=-3.42, p<.05, r=-.53)$. According to the effect size values of this difference, the students' structured problem-posing skills showed a statistically significant improvement in all three groups.

\section{Table 7}

The Analysis of Pretest Scores in the Structured Problem-Posing Skills Sub-Dimension

\begin{tabular}{|c|c|c|c|c|c|}
\hline Groups & $n$ & Mean rank & Rank total & $U$ & $p$ \\
\hline I. Experiment & 22 & 20.64 & 454 & \multirow{2}{*}{201} & \multirow{2}{*}{.47} \\
\hline Control & 21 & 23.43 & 492 & & \\
\hline II. Experiment & 20 & 21.13 & 422.50 & \multirow{2}{*}{207.50} & \multirow{2}{*}{.95} \\
\hline Control & 21 & 17.26 & 362.50 & & \\
\hline I. Experiment & 22 & 19.45 & 428 & \multirow{2}{*}{175} & \multirow{2}{*}{.26} \\
\hline II. Experiment & 20 & 23.75 & 475 & & \\
\hline
\end{tabular}

\section{Table 8}

The Analysis of Posttest Scores in the Structured Problem-Posing Skills Sub-Dimension

\begin{tabular}{|c|c|c|c|c|c|}
\hline Groups & $n$ & Mean rank & Rank total & $U$ & $p$ \\
\hline I. Experiment & 22 & 26.66 & 586.50 & \multirow{2}{*}{128.50} & \multirow{2}{*}{$.01 *$} \\
\hline Control & 21 & 17.12 & 359.50 & & \\
\hline II. Experiment & 20 & 24.93 & 498.50 & \multirow{2}{*}{131.50} & \multirow{2}{*}{$.04^{*}$} \\
\hline Control & 21 & 17.26 & 362.50 & & \\
\hline I. Experiment & 22 & 22.43 & 493.50 & \multirow{2}{*}{199.50} & \multirow{2}{*}{.60} \\
\hline II. Experiment & 20 & 20.48 & 409.50 & & \\
\hline
\end{tabular}

\section{Table 9}

The Analysis of the Pretest and Posttest Scores in the Structured Problem-Posing Skills Sub-Dimension

\begin{tabular}{|c|c|c|c|c|c|c|}
\hline Groups & Pretest posttest & $\mathrm{n}$ & Mean rank & Rank total & $z$ & $p$ \\
\hline \multirow{3}{*}{ I. Experimental group } & Negative ranks & $0^{a}$ & .00 & .00 & \multirow{3}{*}{$-4.11^{*}$} & \multirow{3}{*}{.00} \\
\hline & Positive ranks & $22^{b}$ & 11.50 & 253.00 & & \\
\hline & Equal & $0^{\circ}$ & - & - & & \\
\hline \multirow{3}{*}{ II. Experimental group } & Negative ranks & $0^{a}$ & .00 & .00 & \multirow{3}{*}{$-3.92^{*}$} & \multirow{3}{*}{.00} \\
\hline & Positive ranks & $20^{b}$ & 10.50 & 210.00 & & \\
\hline & Equal & $0^{\circ}$ & - & - & & \\
\hline \multirow{3}{*}{ The control group } & Negative ranks & $2^{a}$ & 8.50 & 17 & \multirow{3}{*}{$-3.42^{*}$} & \multirow{3}{*}{.00} \\
\hline & Positive ranks & $19^{b}$ & 11.26 & 214 & & \\
\hline & Equal & $0^{\circ}$ & - & - & & \\
\hline
\end{tabular}


The results of the Mann-Whitney $U$ test conducted for the analysis of the semi-structured problem-posing skills sub-dimension pretest scores of the experimental and control groups are presented in Table 10.

According to Table 10, before the practices among the groups, no statistically significant difference was observed $(U=187.50, z=-1.06, p>.05 ; U=173.50, z=-.95$, $p>.05 ; U=216, z=-.10, p>.05)$. The results of the mean ranks of the groups revealed that the semi-structured problem-posing skills were equivalent in each of the three groups before the application of learning methods.

The outcomes of the Mann-Whitney $U$ test conducted for the analysis of the semi-structured problem-posing skills sub-dimension posttest scores of the experimental and control groups are shown in Table 11.
According to Table 11, after the experimental applications, no statistically significant difference was observed between the groups $(U=208.50, z=-.55, p>$ $.05 ; U=162, z=-1.25, p>.05 ; U=180 z=-1.01, p>.05)$. The results of the mean ranks of the groups revealed that semi-structured problem-posing skills did not differ in all three groups after the implementation of learning methods.

The findings of the Wilcoxon signed ranks test conducted to determine whether a statistically significant difference between the pretest and posttest scores of the sub-structured problem-posing skills sub-dimension of the students in the experimental and control groups is presented in Table 12.

According to Table 12, in the experimental and control groups, a statistically significant difference was found in favor of posttest scores $(z=-3.49, p<.05, r=-.53$;

\section{Table 10}

The Analysis of the Pretest Scores in Semi-Structured Problem-Posing Skills Sub-Dimension

\begin{tabular}{|c|c|c|c|c|c|}
\hline Groups & $n$ & Mean rank & Rank total & $U$ & $p$ \\
\hline I. Experiment & 22 & 23.98 & 527.50 & \multirow{2}{*}{187.50} & \multirow{2}{*}{.29} \\
\hline Control & 21 & 19.93 & 418.50 & & \\
\hline II. Experiment & 20 & 22.83 & 456.50 & \multirow{2}{*}{173.50} & \multirow{2}{*}{.34} \\
\hline Control & 21 & 19.26 & 404.50 & & \\
\hline I. Experiment & 22 & 21.32 & 469 & \multirow{2}{*}{216} & \multirow{2}{*}{.92} \\
\hline II. Experiment & 20 & 21.70 & 434 & & \\
\hline
\end{tabular}

Table 11

The Analysis of the Posttest Scores in Semi-Structured Problem-Posing Skills Sub-Dimension

\begin{tabular}{|c|c|c|c|c|c|}
\hline Groups & $n$ & Mean rank & Rank total & $U$ & $p$ \\
\hline I. Experiment & 22 & 23.02 & 506.50 & \multirow{2}{*}{208.50} & \multirow{2}{*}{.58} \\
\hline control & 21 & 20.93 & 439.50 & & \\
\hline II. Experiment & 20 & 23.40 & 468 & \multirow{2}{*}{162} & \multirow{2}{*}{.21} \\
\hline control & 21 & 18.71 & 393 & & \\
\hline I. Experiment & 22 & 19.68 & 433 & \multirow{2}{*}{180} & \multirow{2}{*}{.31} \\
\hline II. Experiment & 20 & 23.50 & 470 & & \\
\hline
\end{tabular}

\section{Table 12}

Analysis of Pretest and Posttest Scores of the Semi-Structured Problem-Posing Skills Sub-Dimension

\begin{tabular}{|c|c|c|c|c|c|c|}
\hline Groups & Pretest posttest & $n$ & Mean rank & Rank total & $z$ & $p$ \\
\hline \multirow{3}{*}{ I. Experimental group } & Negative ranks & $4^{a}$ & 4.75 & 19 & \multirow{3}{*}{$-3.49^{*}$} & \multirow{3}{*}{.00} \\
\hline & Positive ranks & $18^{b}$ & 13 & 234 & & \\
\hline & Equal & $0^{\circ}$ & - & - & & \\
\hline \multirow{3}{*}{ II. Experimental group } & Negative ranks & $1^{a}$ & 1 & 1 & \multirow{3}{*}{$-3.88^{*}$} & \multirow{3}{*}{.00} \\
\hline & Positive ranks & $19^{b}$ & 11 & 209 & & \\
\hline & Equal & $0^{\circ}$ & - & - & & \\
\hline \multirow{3}{*}{ The control group } & Negative ranks & $4^{a}$ & 4.50 & 18 & \multirow{3}{*}{$-3.25^{*}$} & \multirow{3}{*}{.00} \\
\hline & Positive ranks & $16^{b}$ & 12 & 192 & & \\
\hline & Equal & $1^{\circ}$ & - & - & & \\
\hline
\end{tabular}


$z=-3.88, p<.05, r=-.61 ; z=-3.25, p<.05, r=-50)$. According to the effect size values related to this difference, the students' semi-structured problem-posing skills showed a statistically significant increase in all three groups.

The results of the Mann-Whitney $U$ test conducted for the analysis of the free problem-posing skills subdimension pretest scores of the experimental and control groups are shown in Table 13.

According to Table 13, before the practices among the groups, no statistically significant difference was observed $(U=230.50, z=-.01, p>.05 ; U=168.50, z=-1.08$, $p>.05 ; U=176.50, z=-1.10, p>.05)$. When the mean ranks of the groups are observed, it can be stated that free problem-posing skills were equivalent in each of the three groups before the application of learning methods.
The results of the Mann-Whitney $U$ test conducted for the analysis of the free problem-building skills subdimension posttest scores of the experimental and control groups are presented in Table 14.

According to Table 14, after experimental applications, no statistically significant difference was observed between the groups $(U=167.50, z=-1.54, p>.05 ; U=142$, $z=-1.77, p>.05 ; U=209.50, z=-.26, p>.05)$. When the mean ranks of the groups are examined, it can be stated that the free problem-posing skills did not differ in all three groups after the application of learning methods.

The results of the Wilcoxon signed ranks test conducted to determine whether a statistically significant difference between the pretest-posttest scores of the students' free problem-posing skills sub-dimension in the experimental and control groups is presented in Table 15.

\section{Table 13}

Analysis of Pretest Scores of the Free Problem-Posing Skills Sub-Dimension

\begin{tabular}{|c|c|c|c|c|c|}
\hline Groups & $n$ & Mean rank & Rank total & $U$ & $p$ \\
\hline I. Experiment & 22 & 21.98 & 483.50 & \multirow{2}{*}{230.50} & \multirow{2}{*}{.99} \\
\hline Control & 21 & 22.02 & 462.50 & & \\
\hline II. Experiment & 20 & 23.08 & 461.50 & \multirow{2}{*}{168.50} & \multirow{2}{*}{.28} \\
\hline Control & 21 & 19.02 & 399.50 & & \\
\hline I. Experiment & 22 & 19.52 & 429.50 & \multirow{2}{*}{176.50} & \multirow{2}{*}{.27} \\
\hline II. Experiment & 20 & 23.68 & 473.50 & & \\
\hline
\end{tabular}

\section{Table 14}

Analysis of Posttest Scores of the Free Problem-Posing Skills Sub-Dimension

\begin{tabular}{|c|c|c|c|c|c|}
\hline Groups & $n$ & Mean rank & Rank total & $U$ & $p$ \\
\hline I. Experiment & 22 & 24.89 & 547.50 & \multirow{2}{*}{167.50} & \multirow{2}{*}{.12} \\
\hline Control & 21 & 18.98 & 398.50 & & \\
\hline II. Experiment & 20 & 24.40 & 488 & \multirow{2}{*}{142} & \multirow{2}{*}{.08} \\
\hline Control & 21 & 17.76 & 373 & & \\
\hline I. Experiment & 22 & 21.02 & 462.50 & \multirow{2}{*}{209.50} & \multirow{2}{*}{.79} \\
\hline II. Experiment & 20 & 22.03 & 440.50 & & \\
\hline
\end{tabular}

\section{Table 15}

Analysis of Pretest and Posttest Scores of Free Problem-Posing Skills Sub-Dimension

\begin{tabular}{|c|c|c|c|c|c|c|}
\hline Groups & Pretest posttest & $n$ & Mean rank & Rank total & $z$ & $p$ \\
\hline \multirow{3}{*}{ I. Experimental group } & Negative ranks & $1^{a}$ & 7 & 7 & \multirow{3}{*}{$-3.77^{*}$} & \multirow{3}{*}{.00} \\
\hline & Positive ranks & $20^{b}$ & 11.20 & 224 & & \\
\hline & Equal & $1^{\circ}$ & - & - & & \\
\hline \multirow{3}{*}{ II. Experimental group } & Negative ranks & $5^{a}$ & 4.60 & 23 & \multirow{3}{*}{$-3.06^{*}$} & \multirow{3}{*}{.00} \\
\hline & Positive ranks & $15^{b}$ & 12.47 & 187 & & \\
\hline & Equal & $0^{\circ}$ & - & - & & \\
\hline \multirow{3}{*}{ The control group } & Negative ranks & $7^{a}$ & 11.21 & 78.50 & \multirow{3}{*}{$-.99^{*}$} & \multirow{3}{*}{.32} \\
\hline & Positive ranks & $13^{b}$ & 10.12 & 131.50 & & \\
\hline & Equal & $1^{\circ}$ & - & - & & \\
\hline
\end{tabular}


According to Table 15, in the first experimental group, $(z=-3.77, p<.05, r=-.57)$ and in the 2 nd experimental group $(z=-3.06, p<.05, r=-.48)$, there was a statistically significant difference in favor of posttest scores, while no statistically significant difference $(z=-.99$, $p>$.05) was observed in the control group. Also the effect size values revealed that the first experimental group was found to make significant progress in the problem-posing skills, while the second experimental group showed moderate improvement. However, the learning process envisaged by the curriculum was not effective in the development of free problem-posing skills of the students in the control group.

\section{Conclusion and Discussion}

By examining the teachers' opinions, the curriculum, and the relevant literature, the method that could be effective in making the students gain problem-solving and problem-posing skills were determined as the inquiry-based learning method. The inquiry-based learning is seen as a process in which the problems or questions are formed, and the students, during the course, try to solve problems or find answers to the problems (Hammerman, 2006; Llewellyn, 2002; Wood, 2003).

The findings revealed that the courses carried out with the inquiry method increased students' success, developed their scientific process skills, led to a positive attitude toward the course of science and technology, developed their learning of concept, improved their academic self-efficacy, and inquiry-based activities were applicable in the preschool period (Çakar, 2013; Duban, 2008; E†i, 2016; Gençtürk \& Türkmen, 2007; Kayacan, 2014; Ünal, 2018).

According to these results, the application of inquiry processes foreseen by the curriculum allows students to structure their knowledge by developing independent questions. Based on these results, the inquiry-based learning method was adopted as the method used in the second part of the study.

The findings of the second part of the study revealed that the methods applied in the experimental groups were more effective than the control group and improved the students' problem-solving skills. Among the applied methods, it was concluded that the inquiry-based learning method supported by metacognitive strategies was more effective than the inquiry-based learning method.

The courses carried out with the inquiry-based learning method supported by metacognitive strategies have an effect on the improvement of students' problemsolving skills. In a similar vein, Izzati and Mahmudi (2018) emphasized that metacognition is necessary to solve mathematical problems successfully. They found that students with higher metacognition are also better problem-solvers. Goldberg and Bush (2003) claimed that the metacognition process used in mathematical problem solving improves students' problem-solving performance and metacognition skills. Özsoy (2007) examined the effect of metacognitive strategies teaching on the students' success in problem-solving stages suggested by Polya. The findings revealed that teaching metacognitive strategies through metacognitive problem-solving activities increased students' problem-solving success.

Mevarech and Kramarski (1997) argued that the IMPROVE strategy, a metacognitive strategy, used in their study contributed to the students' success in some areas such as mathematical thinking, problemsolving, and reasoning. Vula et al. (2017) claimed that the use of metacognitive strategy and self-regulation processes was effective on students' actions, reasoning, and reflections. The findings of these studies coincide with the findings of this research. Thus, it would be safe to say that the use of various metacognitive strategies in the problem-solving process improves the students' problem-solving skills. The strategies used in the problem-solving process help the students decide which steps to complete the task and transmit their experiences to the subsequent tasks, as these strategies are conscious, and they contain awareness and control. Moreover, materials prepared to use these strategies (guidance card worksheet, behavior card worksheet, problem-solving worksheet, peer assessment form, etc.) could be considered factors that improve students' problem-solving skills.

It was observed that the activities performed by the inquiry-based learning method were effective in improving students' problem-solving skills. Polat (2009) argued that the interrogative problem-solving approach improves students' problem-solving skills, offers new solutions through in-class discussions and teaches them to think differently. These results are also consistent with the results of this study. Furthermore, previous studies demonstrated that the effect of inquiry-based learning on unsuccessful students' grades was strong and permanent (Kogan \& Laursen, 2013), the students enjoyed the lessons during the inquiry-based learning process, there was an improvement in their behaviors and motivations, and their success of mathematics increased (Camenzuli \& Buhagiar, 2014; Caswell \& LaBrie, 2017), and the questioning skills of the teacher trainees and their anxiety levels related to the mathematics teaching had an inverse relationship (Yavuz et al., 2018).

The findings on the students' problem-posing skills revealed that the applied methods were more effective in developing students' structured problem- 
posing skills among the groups. No statistically significant difference was observed among the groups in the other sub-dimensions. Furthermore, while studies conducted on the sub-dimensions developed the students' structured, semi-structured, and free problem-posing skills in all three groups, no improvement was observed in the students' free problem-posing skills only in the control group. This situation revealed that studies conducted in the experimental groups were effective, whereas inadequate in the control group.

The materials concerning how the activities would be performed in the experimental groups (error evaluation form, checklist, reflective journal writing form, etc.) were considered the factors that improved students' problem-posing skills. Tertemiz and Sulak (2013) argued that most of the students developed problems by changing the values of the data at hand without changing the technical conditions and the subject. It was identified that there would be no problem in the classifications of "reversing the given and requested information" and "changing the conditions without changing the given data and the subject."

Ngah et al. (2016) found that free problem-posing was a more challenging task than semi-structured and structured problem-posing situations. Similarly, Özgen et al. (2017) found that while there was no statistically significant difference between students' ability to construct different problems, it was found that the students had more difficulty in the free problemposing activities. According to these results, it would be safe to say that the results obtained in this research were similar to the results of the relevant studies. The main reason for this is that, in structured problemposing skills, the students could produce problems more easily than the ready-made problem situations. Although there were raw data such as pictures, tables, and figures for students to use in semi-structured problem situations, they had difficulties in forming problems by combining these data. Likewise, in the cases of free problem-posing, the limited information that would serve as an example for students led them to have difficulty in developing problems. Therefore, it would be useful to include different problem-posing activities frequently in mathematics classes.

Teachers' inadequate information about the problemposing can be considered one of the reasons why students cannot develop problems related to different problem situations. Işık and Kar (2012) found that primary school mathematics teachers included structured and semi-structured problem-posing activities in the process of the course, whereas they did not engage in free problem-building activities.
The other reason would be the insufficient number of activities in the textbooks for students to work with different problem situations. Fewer problem-posing activities prevent students from being productive by seeing different problem situations. Regarding this subject, Issık (2010) found that the problem-posing strategies in mathematics textbooks have not reached the desired prevalence level yet.

Arıkan and Ünal (2013) argued that the students could not develop a problem in line with the desired situation and that this was due to the fact that the problem-posing activity in the book is not appropriate for students' readiness levels. According to Cai and Jiang (2016), the problem-posing tasks should be included more in the textbooks both in China and the US, depending on the class levels, the problem-solving diversity, and the designs of problem-solving tasks. EvCimen and Yıldız (2017) pointed out that the problemposing activities in all textbooks that they examined were included in a limited number and variety in all textbooks except for the eighth-grade textbook of a private publishing company. In addition, it was observed that the problem-posing activities were not in a balanced distribution in sub-learning areas and that there was no textbook covering all learning areas and all types of problem-posing. Therefore, it would be effective to include an adequate number of different problem-posing activities in mathematics textbooks.

\section{Suggestions}

- Methods that encourage students to conduct research and solve problems should be preferred by the teachers to help students gain problem-solving and problem-posing skills.

- Learning environments should be prepared by the teachers in which the students could activate their metacognition skills in the process of asking questions, researching, analyzing information, and transforming data into useful information in the problem-solving and problem-posing stages.

- Organizing pre-service and in-service training might help teachers and prospective teachers learn about metacognition and inquiry-based learning.

- It will be beneficial for the teachers and students to use the materials developed by the researchers to improve metacognition in the learning process.

- Training can be organized for the teachers to design and implement in-class practices in which different problem-posing activities are conducted. 
- Problem-posing skill is as important as problemsolving skill and it should not be considered separately from problem-solving skill. Therefore, by considering this situation in teacher training programs, the arrangements should be made for the importance of problem-posing in the problem-solving process and the improvement of problem-posing skills.

- In this research, as a result of experimental practices, students' problem-solving and problem-posing skills development were examined. In addition, further studies would be helpful to examine the effect of students' problem-forming skills on problem-solving skills.

- The inquiry-based learning method supported by metacognitive strategies was conducted in a quantitative dimension. Future studies employing qualitative methods could examine the views of teachers and students about this process.

- This research was conducted in accordance with the problem-solving and problem-posing gains in primary school fourth-grade mathematics course. Experimental research can be conducted in different subject areas, courses, and grade levels using the inquiry-based learning method supported by metacognitive strategies.

\section{References}

Akkaş, E. (2014). The effects of differentiated problemsolving instruction on mathematical problem solving, attitudes and creative thinking of gifted and talented learners [Unpublished doctoral dissertation]. Abant İzet Baysal University.

Arıkan, E. E., \& Ünal, H. (2013). The analysis of mathematical problem posing skill of elementary second grade students. Amasya Education Science, 2(2), 305-325.

Aşık, G. (2015). A design study on metacognitive training in problem solving [Unpublished doctoral dissertation]. Marmara University.

Ayre, C., \& Scally, A. J. (2014). Critical values for lawshe's content validity ratio: Revisiting the original methods of calculation. Measurement and Evaluation in Counseling and Development, 47(1), 79-86. https://doi.org/10.1177/0748175613513808

Barın, S. (2016). The effect of metacognitive strategy use support in problem solving processes in case-based online learning environments [Unpublished master's thesis]. Hacettepe University.
Baykul, Y. (2014). Ilkokulda matematik öğretimi [Teaching mathematics in primary school] (12th ed.). Pegem Akademi.

Blakey, E., \& Spence, S. (1990). Developing metacognition. ERIC Digest [on-line]. ERIC Clearing house on Information Resources Syracuse NY.

Büyüköztürk, Ş. (2012). Sosyal bilimler için veri analizi el kitabı [Manual of data analysis for social sciences]. Pegem Akademi.

Cai, J., \& Hwang, S. (2002). Generalized and generative thinking in US and Chinese students' mathematical problem solving and problem posing. The Journal of Mathematical Behavior, 21(4), 401-421.

Cai, J., \& Jiang, C. (2016). An analysis of problemposing tasks in Chinese and US elementary mathematics textbooks. International Journal of Science and Mathematics Education, 15, 15211540.https://doi.org/10.1007/s10763-016-9758-2

Camenzuli, J., \& Buhagiar, M. A. (2014). Using inquirybased learning to support the mathematical learning of students with SEBD. The International Journal of Emotional Education, 6(2), 69-85.

Caswell, C. J., \& LaBrie, D. (2017). Inquiry based learning from the learner's point of view: A teacher candidate's success story. Journal of Humanistic Mathematics, 7(2), 161-186.

Creswell, J. W., \& Plano-Clark, V. L. (2015). Karma yöntem araştırmaları tasarımı ve yürütülmesi [Design and execution of mixed method researches]. (Y. Dede \& S. B. Demir, Trans.). Anı Yayıncllık.

Çakar, E. (2013). The effects of inquiry based learning in science and technology course on students' achievements, conceptlearning, metacognition awareness and attitudes towards science and technology course [Unpublished doctoral dissertation]. Ege University.

Divrik, R. (2020). The effect of problem posing-based mathematics teaching on fourth gradestudents' problem solving skills and metacognitive awareness levels. Turkish Studies-Education, 15(3), 1729-1750. https://dx.doi.org/10.29228/ TurkishStudies. 41503

Duban, N. (2008). Conducting science and technology course through inquiry-based learning approach in primary education: An action research [Unpublished doctoral dissertation]. Anadolu University. 
English, L. D. (2003). Engaging students in problem posing in an inquiry-oriented mathematics classroom. In F. Lester, \& R. Charles (Eds.), Teaching mathematics through problem solving (pp. 187-198). National Council of Teachers of Mathematics.

Erdoğan, F. (2013). Research on the effect of cooperative learning method enhanced with metacognitive strategies, on the academic achievement, metacognitive skills and attitude towards mathematics of 6th grade students in mathematics teaching [Unpublished doctoral dissertation]. Marmara University.

Erümit, A. K. (2014). Artificial intelligence-based learning environments which preparing Polya's problem solving steps effect on students' problem solving processes [Unpublished doctoral dissertation]. Karadeniz Teknik University.

Eti, i. (2016). Action research on developing inquirybased science activities in early childhood education [Unpublished doctoral dissertation]. çukurova University.

Ev-Çimen, E., \& Yıldız, S.. (2017). An investigation of problem posing activities in secondary school mathematics textbooks. Turkish Journal of Computer and Mathematics Education, 8(3), 378-407. https://doi.org/10.16949/ turkbilmat.291814

Field, A. (2009). Discovering statistics using IBM SPSS (3th ed.). Sage.

Flavell, J. H. (1979). Metacognitive and cognitive monitoring: A new area of cognitivedevelopment inquiry. American Psycholist, 34(10), 906-911.

Gama, A. C. (2004). Integrating metacognition instruction in interactive learning environments [Unpublished doctoral dissertation]. University of Sussex, Sussex Weald in East Sussex.

Gençtürk, H. A., \& Türkmen, L. (2007). A study of effectiveness and application of inquiry method in a 4th grade science course. Gazi Eğitim Fakültesi Dergisi, 27(1), 277-292.

Georghiades, P. (2004). From the general to the situated: Three decades of metacognition. International Journal of Science Education, 26(3), 365-383.
Goldberg, P. D., \& Bush, W. S. (2003). Using metacognitive skills to improve 3rd graders' math problem solving. Focus on Learning Problems in Mathematics, 5(10), 29-48.

Gonzales, N. A. (1998). A blueprint for problem posing. School Science \& Mathematics, 9(8).

Hammerman, E. (2006). 8 essentials of inquiry-based science, K-8. Corwin Press.

Işık, Ö. (2010). Primary 4, 5, 6 installation problem in terms of mathematics books for classes investigation activities thesis of graduate degree [Unpublished master's thesis]. Cumhuriyet University.

Işık, C., \& Kar, T. (2012). A qualitative study on teacher views of problem posing in mathematics lesson. Milli Eğitim, 41(194), 199-215.

Izzati, L. R., \& Mahmudi, A. (2018). The influence of metacognition in mathematical problem solving. IOP Conf. Series: Journal of Physics: Conf. Series, 1097(1), 1-7. https://doi.org/10.1088/17426596/1097/1/012107

Kanbur Tekerek, B., \& Argün, Z. (2019). Investigation of pre-service elementary mathematics teachers' problem posing situations in dynamic geometry environment. Pegem Eğitim ve Öğretim Dergisi, 9(1), 125-148. http://dx.doi.org/10.14527/ pegegog.2019.005

Karataş, i., \& Baki, A. (2017). The effect of learning environments based on problem solving on students' achievements of problem solving. International Electronic Journal of Elementary Education, 5(3), 249-268.

Katrancl, Y. (2014). The effect of problem posing studies on mathematical understanding and problem solving achievement in cooperative learning environments [Unpublished doctoral dissertation]. Marmara University.

Kayacan, K. (2014). The effect of inquiry based learning enriched with self regulated activities on preservice science teachers' conceptual understanding about force and motion and academic self efficacy [Unpublished doctoral dissertation]. Gazi University.

Keller, T. J. (2001). From theory to practice creating an inquiry-based science classroom [Unpublished doctoral dissertation]. University of Pasific Lutheran. 
Kilpatrick, J. (1987). Problem formulating: where do good problems come from? In A. H. Schoenfeld (Eds.), Cognitive Science and Mathematics Education (pp. 123-147). Erlbaum.

Kogan, M., \& Laursen, S. L. (2013). Assessing long-term effects of inquiry-based learning: A case study from college mathematics. Innovative Higher Education, 39, 183-199. https://doi.org/10.1007/ s10755-013-9269-9

Lawshe, C. H. (1975). A quantitative approach to content validity. Personnel Psychology, 28, 563575 .

Lin, X. (2001). Designing metacognitive activities. Educational Technology Research and Development, 49(2), 23-40.

Llewellyn, D. (2002). Inquiry within: Implementing inquiry-based science standards. Corwin Press.

Lowrie, T. (2002). Young children posing problems: the influence of teacher intervention on the type of problems children pose. Mathematics Education Research Journal, 14(2), 87-98.

Mamona-Downs, J. (1993). On analysing problem posing. In I. Hirabayashi, N. Nohada, K. Shigematsu, \& F. L. Lin (Eds.), Proceedings of the 17th Conference of the International Group for the Psychology of Mathematics Education (Vol. 3, pp. 41-47). Tsukuba, Japan.

Mayer, R. E. (2002). Invited reaction: Cultivating problem solving skills through problem based approaches to professional development. Human Resource Development Quarterly, 13(3), 243-261.

Mevarech, Z. R., \& Kramarski, B. (1997). IMPROVE: A Multidimensional method for teaching mathematics in heterogeneous classrooms. American Educational Research Journal, 34, 365-394.

MoNE (2005). ilköğretim matematik dersi 1-5. sınıflar öğretim programı [Elementary mathematics lesson 1-5. classes curriculum]. MEB.

MoNE (2015). ilkokul matematik dersi (1, 2, 3 ve 4. sınıflar) öğretim programı. [Primary school mathematics curriculum (1st, 2nd, 3rd and 4th grades)]. MEB. http://ttkb.meb.gov.tr/
MoNE (2018). Matematik dersi öğretim programı (ilkokul ve ortaokul 1, 2, 3, 4, 5, 6, 7 ve 8. siniflar) [Mathematics curriculum (Primary and secondary school 1, 2, 3, 4, 5, 6, 7 and 8th grades)]. MEB. http://ttkb.meb.gov.tr/

NCTM (2000). Principles and standards for school mathematics. NCTM.

Nelson, L. L. (2012). The effectiveness of metacognitive strategies on 8th grade students in mathematical achievements and problem solving skills [Unpublished doctoral dissertation]. The Graduate School Southern University and A\&M College.

Ngah, N., Ismail, Z., Tasir, Z., \& Said, M. N. H. M. (2016). Students' ability in free, semi-structured and structured problem posing situations. Advanced Science Letters, 22(12), 4205-4208.

Özgen, K. Aydın, M., Geçici, M. E., \& Bayram, B. (2017). Investigation of problem posing skills of eighth grade students in terms of some variables. Turkish Journal of Computer and Mathematics Education, 8(2), 218-243. https://doi.org/10.16949/ turkbilmat.322660

Özsoy, G. (2007). The effect of metacognitive instruction on problem solving achievement of fifth grade primary school students [Unpublished doctoral dissertation]. Gazi University.

Perry, V. R., \& Richardson, C. P. (2001). The new mexico tech master of science teaching program: An exemplary model of inquiry-based learning. 31st ASEE/IEEE Frontiers in Education Conference, Reno.

Polat, Z. S. (2009). The effects of problem solving approaches on students' performance and self-regulated learning in mathematics [Unpublished doctoral dissertation]. Middle East Technical University.

Pugalee, D. (2001). Writing, mathematics, and metacognition: looking for connections through students' work in mathematical problem solving. School Science and Mathematics. 101(5), 236-245

PRIMAS Project (2010). Handouts for teachers. https:// primas-project.eu/. 
Rosli, R. B. (2013). The integration of problem posing in teaching and learning of mathematics [Unpublished doctoral dissertation]. Office of Graduate Studies of Texas A\&M University.

Schoenfeld, A. H. (1987). What's all the fuss about metacognition? In A. Schoenfeld (Eds.), Cognitive science and mathematics education (pp. 189-215). Lawrence Erlbaum.

Schraw G. (1998). Promoting general metacognitive awareness. Instructional Science, 26, 113-125.

Schraw, G., \& Moshman, D. (1995). Metacognitive theories. Educational Psychology Review, 7(4), 351-371.

Senemoğlu, N. (2013). Gelişim, öğrenme ve öğretim: Kuramdan uygulamaya [Development, learning and teaching: From theory to practice] (23th ed.). Yargı Yayınevi.

Silver, E. A. (1994). On mathematical problem posing. For the Learning of Mathematics, 14(1), 19-28.

Silver, E. A., \& Cai, J. (2005). Assessing students' mathematical problem posing. Teaching Children Mathematics, 12(3), 129-135.

Stoyanova, E., \& Ellerton, N. F. (1996). A framework for research into students' problem posing. In P. Clarkson (Eds.), Technology in mathematics education (pp. 518-525). Mathematics Education Research Group of Australasia.

Tertemiz (Işık), N., \& Sulak, S. E. (2013). The examination of the fifth-grade students' problem posing skills. Elementary Education Online, 12(3), 713-729.

Tian, A. A. (2016). The effect of metacognitive instructional method on eleventh grade students' metacognitive skill and mathematical procedural and conceptual knowledge [Unpublished doctoral dissertation]. Middle East Technical University.

Turhan, B., \& Güven, M. (2014). The effect of mathematics instruction with problem posing approach on problem solving success, problem posing ability and views towards mathematics. Cukurova Üniversitesi Eğitim Fakültesi Dergisi, 43(2), 217-234. https://doi.org/10.14812/cufej.2014.021
Ünal, A. (2018). Effects of the inquiry based and social network aided laboratory activities on students' various perceptions, attitudes and success [Unpublished doctoral dissertation]. Kastamonu University

Vula, E., Avdyli, R., Berisha, V., Sagipi B., \& Elezi, S. (2017). The impact of metacognitive strategies and self-regulating processes of solving math word problems. International Electronic Journal of Elementary Education, 10(1), 49-59.

Weaver, S. O. (2012). The effects of metacognitive strategies on academic achievement, metacognitive awareness, and satisfaction in an undergraduate online education course [Unpublished doctoral dissertation]. University of South Alabama.

Wiersma, W., \& Jurs, S. G. (2005). Research methods in education (8th ed.). Allyn and Bacon.

Wood, W. B. (2003). Inquiry-based undergraduate teaching in the life sciences at large research universities: A perspective on the boyer commision report. Cell Biology Education, 2, 112116.

Woolfolk, A. (2001). Educational Psychology. Allyn and Bacon.

Yavuz, G., Arslan, C.., \& Batdal Karaduman, G. (2018). The relation between prospective mathematics teachers' inquiry skills and mathematics teaching anxiety. Turkish Studies Educational Sciences, 13(11), 1461-1471. http://dx.doi. org/10.7827/TurkishStudies.13360

Yazlık, D. Ö. (2015). Design, application, assessment and the effect of students' achievement of individualized web based mathematic learning environment based on problem solving steps [Unpublished doctoral dissertation]. Selçuk University.

Yıldırım A., \& Şimşek, H. (2006). Sosyal bilimlerde nitel araştırma yöntemleri [Qualitative research methods in social science] (6th ed.). Seçkin Yayıncllık.

Yıldırım, N. (2015). Meta analiz [Meta-analysis]. In M. Metin (Eds.), Eğitimde bilimsel araştırma yöntemleri [Scientific research methods in education] (pp. 137-159). Pegem Akademi. 
Yin, R. K. (1984). Case study research: Design and methods (3th ed.). Sage Publications.

Yurdugül H. (2005). Using content validity indices for content validity in scale development studies. XIV. Ulusal Eğitim Bilimleri Kongresi (pp. 1-6). 2830 Eylül. Denizli.

Yurdugül, H., \& Bayrak, F. (2012).Content validity measures in scale development studies: Comparison of content validity index and kappa statics. H. U. Journal of Education, Special Issue 2, 264-271.

Zhang, L. (2015). The effect of inquiry-based learning on higher vocational students in China: An exploratory study [Unpublished doctoral dissertation]. Indiana State University the College of Graduate and Professional Studies Department of Teaching and Learning. 


\section{Appendix}

\section{EXPERIMENTAL GROUP GUIDANCE CARD WORKSHEET}

Problem: Göktuğ is now 18 years old. Age of his father is 3 times the age of Göktuğ. In two years, what will be the sum of their ages?

\section{Simplify and Represent}

1. Read aloud a few times until you understand the problem and underline important information.

2. Is there an expression in the problem that you do not know the meaning of? If so, what is it?

3. Write down what was given and what was asked? Do you think there is some missing or unnecessary information about the problem?

4. Can you write down what you understand from the problem, what you are asked to do?

5. Which information, methods, and tools can be used to solve the problem?

6. Is it difficult for you to solve the problem before you start solving it? If yes, why is it difficult?

\section{Analyze and Solve}

1. Have you previously solved a problem similar to this one? If so, can you explain in what way it is similar?

\section{Solve the Problem:}

2. Which steps you followed to solve the problem?

3. What did you use to solve the problem? (chart, table, figure, etc.)

\section{Interpret and Evaluate}

1. Is the result you found correct? How do you verify it is correct?

2. If your answer is wrong, where do you think you have made a mistake?

3. Are there any places you have difficulty or need to reevaluate while solving?

\section{Communicate and Reflect}

1. Can you summarize what you have learned from the problem?

2. Could you solve the problem in another way?

3. Do you think this study will be useful for solving other problems? 
Problem Situation: Duru reads 25 pages on the first day, 30 pages on the second day, and 50 pages on the third day.

Develop a problem that includes addition and subtraction by adding new information and data to the information in the problem.

Let's Simplify the Problem Situation: To better understand the problem situation, look at what is given, and which variables are listed. $\mathrm{S} / \mathrm{he}$ tries to understand the problem situation by creating simpler questions.

Let's Analyze the Problem Situation: Have I encountered such a problem before to pose the problem? S/he connects with previous information. S/he draws visuals, tables, and graphics that facilitate problem-posing. Each group develops a problem in accordance with its plan.

Let's Pose the Problem:

Let's Interpret and Evaluate the Posed Problem: S/he checks whether the problem is correct. The data related to the problem e.g., tables, graphs are transferred to forms. If $s /$ he's not sure of her/his problem, s/he'll go back to the beginning.

Let's Present and Reflect the Posed Problem: S/he effectively explains and shares the problem $\mathrm{s} /$ he has developed in the classroom. $\mathrm{S} / \mathrm{he}$ tells if there are alternative problems. $\mathrm{S} /$ he tells her/his relationship with other problems. Finally, s/he keeps the report.

Process Review: The importance of the process is emphasized by talking and discussing the problem-posing process. 